\title{
JUSTISI
}

FAKULTAS HUKUM

UNIVERSITAS MUHAMMADIYAH SORONG

P-ISSN : 1979-7532, E-ISSN : 2686-0821 Vol. 6, No. 2. 77-89

\section{Pelaksanaan Kebijakan Keuangan Negara Dalam Penanganan Covid-19}

\author{
A. Sakti Ramdhon Syah R. \\ Fakultas Hukum, Universitas Muhammadiyah Sorong \\ Email : Ramdhansyah44@gmail.com
}

\begin{abstract}
This study aims to analyze the Implementation of State Financial Policy in Handling Covid-19 regarding Perpu Number 1 of 2020 jo. Law Number 2 of 2020. This research method uses the type of normative-juridical legal research, which refers to the legal norms of statutory regulations, as well as legal theories and principles as supporters. This research is descriptive-analytical in nature, with a qualitative approach. The results of this study indicate that regarding the implementation of the State Financial Policy in exceptional circumstances, especially in the handling of Covid-19 be able due to authority and also legislation. Nevertheless, about Article 27 Perpu Number 1 of 2020 jo. Law Number 2 of 2020 has a number of weaknesses that are vulnerable to abuse of power.
\end{abstract}

Keywords : State Policy, State Finance, Legislation, Covid-19.

\begin{abstract}
Abstrak
Penelitian ini bertujuan untuk menganalisis mengenai Pelaksanaan Kebijakan Keuangan Negara Dalam Penanganan Covid-19 berdasarkan Perpu Nomor 1 Tahun 2020 jo. Undang-Undang Nomor 2 Tahun 2020. Metode Penelitian ini menggunakan tipe penelitian hukum normatif-yuridis, yakni mengacu pada norma hukum peraturan perundang-undangan (statute approach), serta teori dan asas hukum sebagai pendukung. Penelitian ini bersifat deskriptif-analitis, dengan pendekatan kualitatif. Hasil Penelitian ini menunjukan bahwa mengenai Pelaksanaan Kebijakan Keuangan Negara dalam keadaan luar biasa, khususnya dalam penanganan Covid-19, dimungkinkan dikarenakan berdasarkan kewenangan dan juga peraturan perundang-undangan. Hanya saja, mengenai Pasal 27 Perpu Nomor 1 Tahun 2020 jo. Undang-Undang Nomor 2 Tahun 2020 memiliki sejumlah kelemahan yang rentan dengan penyalahgunaan kekuasaan.
\end{abstract}

Kata Kunci : Kebijakan Negara, Keuangan Negara, Peraturan Perundang-Undangan, Covid-19.

\section{PENDAHULUAN}

Penyebaran Corona Virus Disease 2019 (Covid-19) yang melanda sejumlah negara di dunia, tak terkecuali Indonesia, memberikan dampak signifikan terhadap ketahanan sebuah Negara. Di Indonesia sendiri, update dari Kementerian Kesehatan Republik Indonesia (Kemenkes RI) per tanggal 24 Mei 2020, pukul 12.00 WIB, di 34 Provinsi tercatat sebanyak 22.271 positif Covid-19 (naik 526 orang dari total sebelumnya), sebanyak 5.402 total pasien yang sembuh (naik 153 orang 
dari total sebelumnya), serta sebanyak 1.372 total yang meninggal (naik 21 orang dari total sebelumnya).

Dalam pembacaan terkait dengan rilis Kemenkes RI tersebut nyata bahwa penyebaran pandemi Covid-19 dari waktu ke waktu menunjukan peningkatan korban jiwa ataupun kerugiankerugian materil dari waktu ke waktu, sehingga berimplikasi terhadap aspek sosial, ekonomi, dan pula kesejahteraan masyarakat. Untuk meredam laju penyebaran Covid-19 serta dalam rangka menjaga ketahanan negara diperlukan berbagai upaya yang dimaknai sebagai misi penyelamatan negara dalam bentuk peraturan. Fokus utamanya yakni menyangkut perihal belanja kesehatan, pembentukan jaring pengaman sosial (social safety net), serta penjagaan dan pemulihan dibidang perekonomian.

Dengan tujuan tersebut, dibentuklah Peraturan Pemerintah Pengganti Undang-Undang (Perpu) Nomor 1 Tahun 2020 tentang Kebijakan Keuangan Negara Dan Stabilitas Sistem Keuangan Untuk Penangan Pandemi Corona Virus Disease (Covid-19) Dan/Atau Dalam Rangka Menghadapi Ancaman Yang membahayakan Perekonomian Nasional Dan/Atau Stabilitas Sistem Keuangan, sebagaimana telah disahkan menjadi Undang-Undang Nomor 2 tahun 2020 tentang Penetapan Peraturan Pemerintah Pengganti Undang-Undang Nomor 1 Tahun 2020 tentang Kebijakan Keuangan Negara Dan Stabilitas Sistem Keuangan Untuk Penangan Pandemi Corona Virus Disease (Covid-19) Dan/Atau Dalam Rangka Menghadapi Ancaman Yang membahayakan Perekonomian Nasional Dan/Atau Stabilitas Sistem Keuangan Menjadi Undang-Undang.

Pembentukan Perpu Nomor 1 Tahun 2020 jo. UU Nomor 2 Tahun 2020 oleh publik direspon secara beragam. Beberapa masalah diantaranya yaitu mengenai materi muatan Pasal 2 ayat (1) huruf, Pasal 12 ayat (2), ataupun Pasal 27. Pasal 2 ayat (1) huruf a mengatur soal penetapan batasan defisit anggaran melampaui 3\% dari PDB selama masa penanganan Covid-19. Kelemahan Pasal tersebut yakni tidak memberikan batas atas yang tegas sehingga dikhawatirkan terjadi penyalahgunaan pelaksanaan kebijakan keuangan negara. Masalah juga timbul terkait materi muatan Pasal 27 yang sampai dimohonkan uji materil di Mahkamah Konstitusi. Pasal ini dinilai dapat memungkinkan terjadi potensi korupsi, sebab Pasal tersebut mengatur perihal penggunaan biaya selama pemulihan masa pandemi tidak dinilai sebagai kerugian negara.

Kemudian dalam Pasal 27 ayat selanjutnya, disebutkan bahwa pejabat pemerintah yang melaksanakan Perpu Nomor 1 tahun 2020 tidak dapat dituntut baik secara perdata maupun pidana. Disebutkan pula tindakan Pejabat TUN yang diambil berdasarkan Perpu Nomor 1 Tahun 2020 
bukanlah merupakan objek gugatan yang dapat diajukan dalam Peradilan Tata Usaha Negara. Akan tetapi oleh karena Perpu Nomor 1 Tahun 2020 telah ditetapkan menjadi Undang-Undang, menurut kalangan ahli hukum dinilai permohonan uji materil ke Mahkamah Konstitusi tersebut tidak lagi relevan.

Salah satu persoalan lainnya yang timbul dari Perpu Nomor 1 Tahun 2020 jo. UU Nomor 2 Tahun 2020, yakni menyangkut materi muatan Pasal 12 ayat (2) yang mengatur mengenai perubahan postur dan/atau rincian APBN dalam rangka pelaksanaan kebijakan keuangan negara dan langkah-langkahnya, diatur dengan Peraturan Presiden (Perpres). Hal ini dinilai dapat mereduksi kewenangan lembaga legislatif yakni DPR dalam menjalankan fungsinya, baik fungsi legislasi maupun fungsi anggaran yang dikhawatirkan dapat melemahkan kedudukan DPR sebagai lembaga yang memiliki wewenang di bidang legislasi dan anggaran.

Dalam Undang-Undang Nomor 12 tahun 2011 tentang Pembentukan Peraturan PerundangUndangan, sebagaimana telah diubah dengan Undang-Undang Nomor 15 Tahun 2019 tentang Perubahan Atas Undang-Undang Nomor 12 Tahun 2011 tentang Pembentukan Peraturan Perundang-undangan (selanjutnya disebut UU P3), disebutkan bahwa Peraturan Presiden adalah Peraturan Perundang-undangan yang ditetapkan oleh Presiden untuk menjalankan perintah Peraturan Perundang-undangan yang lebih tinggi atau dalam menyelenggarakan kekuasaan pemerintahan. Artinya, kewenangan dalam membentuk Perpres merupakan kewenangan yang timbul dari Undang-Undang tertentu. Akan tetapi dalam praktiknya dapat saja timbul kebijakankebijakan pemerintah dalam berbagai bentuk, yang dibentuk oleh karena keadaan rechtsvacuum.

Sebagaimana diketahui bahwa terdapat perbedaan antara Peraturan Presiden dan Peraturan Pemerintah, dimana Peraturan Pemerintah adalah Peraturan Perundang-undangan yang ditetapkan oleh Presiden untuk menjalankan Undang-Undang sebagaimana mestinya. Sedangkan Peraturan Presiden adalah sebagaimana dijelaskan sebelumnya. Dengan kata lain, dalam Peraturan Pemerintah sejatinya tidak ada pembentukan norma baru yang bersifat subjektif selain untuk menjalankan Undang-Undang. Sedangkan Peraturan Presiden dimungkinkan dibentuk norma subjektif sepanjang merupakan delegasian dan tidak bertentangan dengan Peraturan PerundangUndangan.

Berdasarkan persoalan-persoalan yang telah diuraikan sebelumnya, apakah materi muatan Pasal 12 ayat (2) yang mengatur mengenai kebijakan pemerintah dalam mengatur perubahan postur dan/atau rincian APBN dalam rangka pelaksanaan kebijakan keuangan negara dan langkah- 
langkahnya, dapat melemahkan kedudukan DPR sebagai lembaga pembentuk Undang-Undang, sangat menarik untuk dilakukan kajian lebih lanjut.

\section{METODE PENELITIAN}

Metode Penelitian ini menggunakan tipe penelitian hukum normatif-yuridis, yakni mengacu pada norma hukum peraturan perundang-undangan (statute approach), serta teori dan asas hukum sebagai pendukung. Penelitian ini bersifat deskriptif-analitis, dengan pendekatan kualitatif.

\section{PEMBAHASAN}

\section{Perihal Kebijakan Keuangan Negara}

Perihal Keuangan negara di atur dalam Undang-Undang Nomor 17 Tahun 2003 tentang Keuangan Negara (selanjutnya disebut UU Keuangan Negara). Dalam Pasal 1 disebutkan bahwa Keuangan Negara adalah semua hak dan kewajiban negara yang dapat dinilai dengan uang, serta segala sesuatu baik berupa uang maupun berupa barang yang dapat dijadikan milik negara berhubung dengan pelaksanaan hak dan kewajiban tersebut. Lebih lanjut, dalam Pasal 2 disebutkan bahwa keuangan negara meliputi :

a. Hak negara untuk memungut pajak, mengeluarkan dan mengedarkan uang, dan melakukan pinjaman;

b. Kewajiban negara untuk menyelenggarakan tugas layanan umum pemerintahan negara dan membayar tagihan pihak ketiga;

c. Penerimaan Negara;

d. Pengeluaran Negara;

e. Penerimaan Daerah;

f. Pengeluaran Daerah;

g. Kekayaan negara/kekayaan daerah yang dikelola sendiri atau oleh pihak lain berupa uang, surat berharga, piutang, barang, serta hak-hak lain yang dapat dinilai dengan uang, termasuk kekayaan yang dipisahkan pada perusahaan negara/ perusahaan daerah;

h. Kekayaan pihak lain yang dikuasai oleh pemerintah dalam rangka penyelenggaraan tugas pemerintahan dan/atau kepentingan umum;

i. Kekayaan pihak lain yang diperoleh dengan menggunakan fasilitas yang diberikan pemerintah.

Dalam Penjelasan umum UU Keuangan Negara, dasar pemikiran dari dibentuknya UU Keuangan negara adalah dalam rangka pencapaian tujuan bernegara sebagaimana tercantum dalam 
alinea IV Pembukaan Undang-Undang Dasar 1945 dibentuk pemerintahan negara yang menyelenggarakan fungsi pemerintahan dalam berbagai bidang. Pembentukan pemerintahan negara tersebut menimbulkan hak dan kewajiban negara yang dapat dinilai dengan uang yang perlu dikelola dalam suatu sistem pengelolaan keuangan negara.

Penguasaan terhadap keuangan negara dipegang oleh Presiden selaku kepala pemerintahan yang dianggap merupakan bagian dari kekuasaan pemerintahan. Kekuasaan pemerintahan tersebut selanjutnya dikuasakan kepada :

a. Menteri keuangan selaku wakil dari pemerintah dalam kepemilikan kekayaan negara yang dipisahkan;

b. Menteri/pimpinan lembaga selaku Pengguna Anggaran/Pengguna Barang kementerian negara/lembaga yang dipimpinnya;

c. Gubernur/bupati/walikota selaku kepala pemerintahan daerah untuk mengelola keuangan daerah dan mewakili pemerintah daerah dalam kepemilikan kekayaan daerah yang dipisahkan; dan

d. Tidak termasuk kewenangan dibidang moneter, yang meliputi antara lain mengeluarkan dan mengedarkan uang, yang diatur dengan undang-undang. (Pasal 6 ayat 2 UU Keuangan Negara).

Dalam rangka pelaksanaan kekuasaan atas pengelolaan fiskal, berdasarkan Pasal 8 UU Keuangan Negara, Menteri Keuangan mempunyai tugas sebagai berikut :

a) menyusun kebijakan fiskal dan kerangka ekonomi makro;

b) menyusun rancangan APBN dan rancangan Perubahan APBN;

c) mengesahkan dokumen pelaksanaan anggaran; d) melakukan perjanjian internasional di bidang keuangan;

d) melaksanakan pemungutan pendapatan negara yang telah ditetapkan dengan undangundang;

e) melaksanakan fungsi bendahara umum negara;

f) menyusun laporan keuangan yang merupakan pertanggungjawaban pelaksanaan APBN;

g) melaksanakan tugas-tugas lain di bidang pengelolaan fiskal berdasarkan ketentuan undang-undang. 
Selanjutnya, berdasarkan Pasal 9 UU Keuangan Negara, Menteri/pimpinan lembaga sebagai Pengguna Anggaran/ Pengguna Barang kementerian negara/lembaga yang dipimpinnya mempunyai tugas :

a. menyusun rancangan anggaran kementerian negara/lembaga yang dipimpinnya;

b. menyusun dokumen pelaksanaan anggaran;

c. melaksanakan anggaran kementerian negara /lembaga yang dipimpinnya;

d. melaksanakan pemungutan penerimaan negara bukan pajak dan menyetorkannya ke Kas Negara;

e. mengelola piutang dan utang negara yang menjadi tanggung jawab kementerian negara /lembaga yang dipimpinnya;

f. mengelola barang milik/kekayaan negara yang menjadi tanggung jawab kementerian negara /lembaga yang dipimpinnya;

g. menyusun dan menyampaikan laporan keuangan kementerian negara /lembaga yang dipimpinnya;

h. melaksanakan tugas-tugas lain yang menjadi tanggung jawabnya berdasarkan ketentuan undang-undang.

Kemudian menyangkut kekuasaan pengelolaan keuangan daerah yang dikuasakan kepada Gubernur/bupati/walikota selaku kepala pemerintahan daerah, dalam Pasal 10 UU Keuangan Negara diatur sebagai berikut :

(1) Kekuasaan pengelolaan keuangan daerah sebagaimana tersebut dalam Pasal 6 ayat (2) huruf c :

a. dilaksanakan oleh kepala satuan kerja pengelola keuangan daerah selaku pejabat pengelola APBD;

b. dilaksanakan oleh kepala satuan kerja perangkat daerah selaku pejabat pengguna anggaran/barang daerah.

(2) Dalam rangka pengelolaan Keuangan Daerah, Pejabat Pengelola Keuangan Daerah mempunyai tugas sebagai berikut :

a. menyusun dan melaksanakan kebijakan pengelolaan APBD;

b. menyusun rancangan APBD dan rancangan Perubahan APBD;

c. melaksanakan pemungutan pendapatan daerah yang telah ditetapkan dengan Peraturan Daerah; 
d. melaksanakan fungsi bendahara umum daerah;

e. menyusun laporan keuangan yang merupakan per-tanggungjawaban pelaksanaan APBD.

(3) Kepala satuan kerja perangkat daerah selaku pejabat pengguna anggaran/barang daerah mempunyai tugas sebagai berikut :

a. menyusun anggaran satuan kerja perangkat daerah yang dipimpinnya;

b. menyusun dokumen pelaksanaan anggaran;

c. melaksanakan anggaran satuan kerja perangkat daerah yang dipimpinnya;

d. melaksanakan pemungutan penerimaan bukan pajak;

e. mengelola utang piutang daerah yang menjadi tanggung jawab satuan kerja perangkat daerah yang dipimpinnya;

f. mengelola barang milik/kekayaan daerah yang menjadi tanggung jawab satuan kerja perangkat daerah yang dipimpinnya;

g. menyusun dan menyampaikan laporan keuangan satuan kerja perangkat daerah yang dipimpinnya.

Pada dasarnya UU Keuangan Negara masih tetap berlaku, hanya saja dalam Pasal 28 angka 3 Perpu Nomor 1 Tahun 2020 jo. UU Nomor 2 Tahun 2020, beberapa Pasal yakni Pasal 12 ayat (3) beserta penjelasannya, Pasal 15 ayat (5), Pasal 22 ayat (3), Pasal 23 ayat (1), Pasal 27 ayat (3), dan Pasal 28 ayat (3) dalam Undang-Undang Nomor 17 Tahun 2003 tentang Keuangan Negara (Lembaran Negara Republik Indonesia Tahun 2003 Nomor 47, Tambahan lembaran Negara Republik Indonesia Nomor 4286), dinyatakan tidak berlaku sepanjang berkaitan dengan kebijakan keuangan negara untuk penanganan penyebaran Corona Virus Disease 2019 (Covid-19) dan/atau dalam rangka menghadapi ancaman yang membahayakan perekonomian nasional dan/atau stabilitas sistem keuangan berdasarkan Perpu Nomor 1 Tahun 2020 jo. UU Nomor 2 Tahun 2020.

\section{Kedudukan Peraturan Presiden Dalam Pembentukan Peraturan Perundang-Undangan}

Nomenklatur Peraturan Presiden sebelum era reformasi tidak dikenal dalam pembentukan peraturan perundang-undangan di Indonesia. Dalam lampiran TAP MPRS RI Nomor XX Tahun 1966 hanya terdapat nomenklatur Keputusan Presiden, yakni berisi keputusan yang bersifat khusus (einmaligh), adalah untuk melaksanakan ketentuan Undang-Undang Dasar yang bersangkutan, Ketetapan MPR dalam bidang eksekutif atau Peraturan Pemerintah. Begitu juga dalam Pasal 3 ayat (6) TAP MPR Nomor III/MPR/2000, disebutkan bahwa, Keputusan Presiden yang bersifat 
mengatur dibuat oleh Presiden untuk menjalankan fungsi dan tugasnya berupa pengaturan pelaksanaan administrasi negara dan administrasi pemerintahan.

Menurut A. Hamid Attamimi (dalam A. Sakti Ramdhon Syah R., 2020), pada dasarnya Keputusan Presiden mengadung 4 (empat) norma hukum, yaitu :

1. Gedelegeerde wettelijkeregels, yakni norma pengaturan yang berdasarkan kewenangan delegatif.

2. Beleidsregels, yakni norma hukum yang menyelenggarakan kebijakan pemerintahan yang tidak terikat atau yang bersifat mandiri.

3. Besluiten van algemene strekking, yakni norma hukum berupa keputusan administratif yang berentang umum.

4. Besluiten gericht tot bepaalde persoon, yakni norma hukum yang berupa keputusan administratif yang ditujukan (adressat) kepada subjek hukum tertentu, atau biasa juga disebut dengan Keputusan TUN.

Nomenklatur perundangan mengenai Peraturan Presiden baru dimuat dalam UndangUndang Nomor 10 tahun 2004 yang telah diganti dengan Undang-Undang Nomor 12 tahun 2011 tentang Pembentukan Peraturan Perundang-Undangan, sebagaimana diubah dengan UndangUndang Nomor 15 tahun 2019 tentang Perubahan Atas Undang-Undang Nomor 12 Tahun 2011 tentang Pembentukan Peraturan Perundang-Undangan (UU P3). Akan tetapi, pengertian yang diberikan Undang-Undang Nomor 10 tahun 2004 mengenai Peraturan Presiden masih cukup terbatas, yakni "Peraturan Presiden adalah Peraturan Perundang-undangan yang dibuat oleh Presiden".

Dalam UU P3 perubahan, pengertian Peraturan Presiden diuraikan lebih panjang, yakni "Peraturan Presiden adalah Peraturan Perundang-undangan yang ditetapkan oleh Presiden untuk menjalankan perintah Peraturan Perundang-undangan yang lebih tinggi atau dalam menyelenggarakan kekuasaan pemerintahan”. Perbedaan antara Peraturan Pemerintah dan Peraturan Presiden, yakni Peraturan Presiden tidak dibentuk atau ditetapkan semata-mata untuk menjalankan perintah undang-undang sebagaimana mestinya. Peraturan presiden ditetapkan oleh Presiden untuk menjalankan perintah peraturan perundang-undangan, sehingga tidak hanya undang-undang saja.

Materi muatan Peraturan Presiden, sebagaimana diatur dalam Pasal 13 UU P3, berisi materi yang diperintahkan oleh Undang-Undang, materi untuk melaksanakan Peraturan Pemerintah, atau 
materi untuk melaksanakan penyelenggaraan kekuasaan pemerintahan. Dijelaskan dalam Penjelasan Pasal 13 UU P3, bahwa "Peraturan Presiden dibentuk untuk menyelenggarakan pengaturan lebih lanjut perintah Undang-Undang atau Peraturan Pemerintah secara tegas maupun tidak tegas diperintahkan pembentukannya”.

Apabila diamati, dalam TAP MPRS RI Nomor XX Tahun 1966 dan TAP MPR Nomor III/MPR/2000, maupun dalam UU P3, substansi hukum dari Keputusan Presiden atau Peraturan Presiden pada dasarnya menekankan pada pemberian kewenangan oleh peraturan perundangundangan kepada pemerintah dibidang admnistrasi negara untuk menjalankan fungsi dan tujuan pemerintahan negara. Istilah "kewenangan" dalam kaidah administrasi negara dapat berbentuk kebijakan maupun kebijaksanaan yang merupakan inti dari fungsi pemerintahan. Hal ini oleh sebab dalam kaidah administrasi negara tidak mempersoalkan apa nama sehari-hari yang digunakan, tetapi fungsi yang dilaksanakan.

Dalam pembentukan suatu kebijakan oleh pemerintahan di suatu negara yang berdasarkan hukum, kebijakan harus dibentuk berdasarkan peraturan perundang-undangan. Akan tetapi, dikarenakan perkembangan kebutuhan masyarakat yang serba cepat kadang-kadang suatu kebijakan dibentuk dimungkinkan tidak atas perintah dari peraturan perundang-undangan, tetapi melalui kewenangan pemerintah karena jabatannya. Hal ini sebab dalam kaidah adminitrasi negara berlaku sebuah asas, yakni asas freies ermessens atau yang biasa juga disebut dengan diskresi.

Dalam Undang-Undang Nomor 30 Tahun 2014 tentang Administrasi Pemerintahan, disebutkan bahwa Diskresi adalah Keputusan dan/atau Tindakan yang ditetapkan dan/atau dilakukan oleh Pejabat Pemerintahan untuk mengatasi persoalan konkret yang dihadapi dalam penyelenggaraan pemerintahan dalam hal peraturan perundang-undangan yang memberikan pilihan, tidak mengatur, tidak lengkap atau tidak jelas, dan/atau adanya stagnasi pemerintahan. Diskresi juga didasarkan pada Pasal 13 UU P3 yang memuat frasa untuk menyelenggarakan pengaturan lebih lanjut perintah Undang-Undang atau Peraturan Pemerintah secara tegas maupun tidak tegas diperintahkan pembentukannya (kursif oleh penulis).

Pelaksanaan diskresi yang merupakan wujud kebijakan dari pemerintah dapat dilakukan dengan cara membentuk peraturan ataupun keputusan dari pemerintah yang bertujuan untuk mengatur persoalan konkret yang terjadi di masyarakat. Di tingkat pusat, kebijakan dapat berupa Peraturan Presiden ataupun Keputusan Presiden, ataupun bentuk peratauran lainnya sepanjang tidak bertentangan dengan peraturan perundang-undangan. 


\section{Pelaksanaan Kebijakan Keuangan Negara Dalam menangani Wabah Covid-19}

Berdasarkan kajian teoritis maupun praktis, pelaksanaan kebijakan keuangan negara berdasarkan peraturan presiden, sebagaimana diatur dalam Perpu Nomor 1 tahun 2020 jo. UndangUndang Nomor 2 tahun 2020, sangat dimungkinkan sekalipun misalnya tidak secara tegas disebutkan dalam peraturan perundang-undangan. Hal ini disebabkan karena dalam tradisi administrasi negara sendiri berlaku sebuah kebiasaan hukum administrasi, yakni freies ermessens ataupun diskresi, yang senantiasa terpelihara hingga sekarang. Akan tetapi dalam suatu negara hukum, segala tindakan pemerintah semestinya mengacu pada dasar hukum tertentu untuk mempertegas wewenang ataupun fungsi pemerintahan yang akan atau sedang dilaksanakan. Kebijakan pemerintah dalam menangani wabah Covid-19 yang dituangkan dalam Perpu Nomor 1 tahun 2020 jo. Undang-Undang Nomor 2 tahun 2020 merupakan suatu usaha untuk konsisten dalam mempertahankan kedudukan Indonesia sebagai negara hukum.

Kebijakan dalam pelaksanaan kebijakan keuangan negara, berdasarkan Pasal 6 ayat (1) Undang-Undang Nomor 17 tahun 2003 tentang Keuangan Negara, menyebutkan bahwa kekuasaan pengelolaan keuangan negara merupakan wewenang Presiden selaku Kepala Pemerintahan, sebagai bagian dari kekuasaan pemerintahan. Dalam keadaan normal, kebijakan perihal keuangan negara mengacu pada undang-undang keuangan negara. Sedangkan dalam keadaan tidak normal (extraordinary), kebijakan pemerintah dalam pengelolaan keuangan negara disesuaikan dengan kondisi nyata yang terjadi di masyarakat, dalam hal ini penyebaran wabah Covid-19. Untuk itulah beberapa Pasal dalam UU Keuangan Negara tidak diberlakukan atas dasar pemikiran memberikan akses yang luar biasa dalam penanganan wabah Covid-19, sebagaimana dijelaskan dalam Penjelasan Perpu Nomor 1 tahun 2020.

Adapun mengenai masalah-masalah norma yang diatur dalam Perpu Nomor 1 Tahun 2020 jo. UU Nomor 2 Tahun 2020 sebagaimana telah disinggung dalam pendahuluan diatas, berdasarkan teori dan asas hukum serta perundang-undangan yang relevan, dapat dijelaskan sebagai berikut. Pertama, mengenai Pasal 2 ayat (1) huruf a angka 1 yang memberikan akses kepada pemerintah dalam menetapkan batasan defisit anggaran, dengan ketentuan dapat melampaui 3\% dari PDB selama masa penanganan wabah Covid-19. Meskipun Pasal ini tidak secara tegas memberikan batasan mengenai berapa presentasi maksimal dari PDB yang dapat dikelola, akan tetapi memberikan batasan tentang keberlakuan dari Pasal ini, yakni hanya terbatas selama masa pandemik dan paling lama sampai dengan berakhirnya Tahun Anggaran 2022. Pada 
Tahun Anggaran 2023, besaran defisit akan dikembalikan menjadi 3\% dari PDB lagi, yang dilakukan secara bertahap. Praktis, hal ini tidak sama dengan penetapan APBN setiap tahun yang melibatkan antara DPR dan Pemerintah dalam kondisi normal.

Kedua, mengenai Pasal 12 ayat 2 yang mengatur tentang pelaksanaan kebijakan keuangan negara, yang berkaitan dengan perubahan postur dan/atau rincian APBN beserta langkahlangkahnya, diatur berdasarkan Peraturan Presiden. Materi muatan Pasal 12 ayat 2 pada intinya mengatur tentang pendelegasian kewenangan (subdelegation), yang dalam kaidah ketatanegaraan sangat dimungkinkan. Kenyataannya, hampir setiap undang-undang terdapat materi muatan yang mengatur tentang pendelegasian kewenangan. Berdasarkan Lampiran II UU P3, pengaturan mengenai pendelegasian kewenangan harus menyebut secara tegas terhadap 2 (dua) hal, yakni ruang lingkup materi muatan yang diatur dan jenis Peraturan Perundang-undangan. Pasal 12 ayat 2 boleh dikatakan telah memenuhi unsur ini, yang dalam klausul Pasal tersebut secara tegas mengatur lingkup dan jenis peraturan perundang-undangan apa, yang menjadi wujud dari kebijakan pemerintah. Dengan demikian, pelaksanaan kebijakan keuangan negara sebagaimana diatur dalam Perpu Nomor 1 Tahun 2020 jo. UU Nomor 2 Tahun 2020, tidak dapat dikatakan telah mereduksi fungsi legislasi dari suatu lembaga negara tertentu, sebab telah dilaksanakan berdasarkan perintah dari undang-undang dan berdasarkan kewenangan.

Ketiga, mengenai Pasal 27 yang masalah utama Pasal ini terletak pada ayat (2) dan ayat (3). Dalam ayat (2), diatur mengenai Anggota KSSK, Sekretaris KSSK, anggota sekretariat KSSK, serta beberapa lembaga-lembaga negara sebagaimana disebutkan dalam ayat ini, tidak dapat dituntut baik secara perdata maupun pidana jika dalam melaksanakan tugas didasarkan pada iktikad baik dan sesuai dengan ketentuan peraturan perundang-undangan. Frasa "didasarkan pada iktikad baik" pada dasarnya hanya mengikat secara moral, walaupun hal ini merupakan tujuan dari politik hukum pemerintah yang bersifat ius operatum. Terlebih lagi kepercayaan publik terhadap kinerja aparatur negara dalam implemetasi public servant mengalami angka penurunan yang cukup drastis. Kebijakan-kebijakan dari unsur-unsur KSSK maupun beberapa lembaga negara sebagaimana disebutkan dalam ayat ini, dalam melakukan perbuatan publik tentu bersandingan dengan ihwal perdata maupun pidana, meskipun dalam beberapa kasus adminitrasi, pemerintah yang dengan kewenangannya melekat pula suatu adhesi yang dapat memaksakan kehendaknya. Pengaturan mengenai tidak dapat dituntutnya unsur-unsur komite KSSK dan beberapa lembaga- 
lembaga sebagaimana disebutkan ayat ini, dikhawatirkan dipandang sebagai penurunan dalam penegakan hukum, khususnya di bidang hukum perdata maupun pidana.

Selanjutnya, mengenai ayat (3) yang mengatur tentang segala tindakan termasuk keputusan yang diambil berdasarkan Perpu Nomor 1 tahun 2020 jo. Undang-Undang Nomor 2 tahun 2020, bukan merupakan objek gugatan yang dapat diajukan kepada peradilan tata usaha negara. Sebagaimana telah diketahui bersama bahwa dalam penyelesaian sengketa TUN, ditentukan mengenai tolok ukur subjek dan pangkal sengketa TUN itu sendiri, yang mana, sengketa administrasi dapat dibedakan lagi atas sengketa intern dan ekstern. Apabila segala tindakan maupun keputusan sebagaimana berdasarkan Perpu Nomor 1 tahun 2020 jo. Undang-Undang Nomor 2 tahun 2020, maka hal ini tidak menimbulkan masalah berarti sebab dapat diselesaikan secara internal. Hal ini juga diatur dalam beberapa peraturan perundang-undangan, meski ada juga pendapat yang menilai bahwa hal ini sedikit banyak akan mengurangi peran pengadilan sebagai lembaga netral dalam hal penyelesaian internal sebagaimana dimaksud.

Akan tetapi manakala tolok ukur subjek dan pangkal sengketa TUN bersifat ekstern, maka hal ini akan menutup kemungkinan kepada individu atau masyarakat untuk mengajukan guguatan manakala terdapat tindakan ataupun suatu keputusan TUN yang dinilai merugikan. Memang, dalam jalur penyelesaian sengketa TUN dapat dilakukan dengan upaya administratif yang juga ditentukan dalam perundang-undangan, namun lazimnya, prosedur upaya admnistratif itu dilakukan di lingkungan pemerintah (banding administratif), yang bisa saja sewaktu-waktu terjadi praktik abuse of power dengan mengatasnamakan peraturan perundang-undangan.

\section{SIMPULAN}

Berdasarkan uraian diatas dapat disimpulkan bahwa dalam hal keadaan luar biasa, dalam hal ini penanganan penyebaran Covid-19, pemerintah karena kewenangannya dan atas perintah undang-undang dimungkinkan untuk mengambil tindakan-tindakan ekstra dengan tujuan penyelamatan negara. Pengaturan mengenai beberapa hal yakni Pasal 2 ayat (1) huruf a angka 1 yang memberikan akses kepada pemerintah dalam menetapkan batasan defisit anggaran, dengan ketentuan dapat melampaui 3\% dari PDB, kemudian Pasal 12 ayat 2 yang mengatur tentang pelaksanaan kebijakan keuangan negara, yang berkaitan dengan perubahan postur dan/atau rincian APBN beserta langkah-langkahnya diatur berdasarkan Peraturan Presiden, merupakan kebijakan-

kebijakan yang diambil dalam keadaan luar biasa. Akan tetapi mengenai Pasal 27, hal-hal yang diatur yakni perihal biaya-biaya yang dikeluarkan tidak dapat dihitung sebagai kerugian negara, 
tak dapat dituntutnya segala tindakan unsur-unsur KSSK dan beberapa lembaga negara, serta segala tindakan termasuk keputusan yang diambil bukan merupakan obyek gugatan TUN, rentan terjadi penyalahgunaan kewenangan.

\section{DAFTAR PUSTAKA}

\section{Buku.}

A. Sakti Ramdhon Syah R., 2020, Perundang-Undangan Indonesia : Kajian Mengenai Ilmu dan Teori Perundang-Undangan serta Pembentukannya, Makassar : CV. Social politic Genius (SIGn).

Ridwan HR, 2014, Hukum Administrasi Negara, PT. RajaGrafindo Persada, Jakarta.

Sahya Anggara, 2016, Administrasi Keuangan Negara, Bandung : CV. Pustaka Setia.

\section{Artikel Jurnal.}

Abdullah Ramdhani, Muhammad Ali Ramdhani, 2017, Konsep Umum Pelaksanaan Kebijakan Publik, Jurnal Publik : Jurnal Ilmiah Bidang Ilmu Administrasi Negara, Vol 11 No 1.

Agus Budi Susilo, 2015, Makna dan Kriteria Diskresi Keputusan Dan/Atau Tindakan Pejabat Publik Dalam Mewujudkan Tata Pemerintahan Yang Baik, Jurnal Hukum dan Peradilan, Vol 4 No 1, DOI: http://dx.doi.org/10.25216/JHP.4.1.2015.133-152

Djoko Suhardjanto, Rena Rukmita Yulianingtyas, 2011, Pengaruh Karakteristik Pemerintah Daerah Terhadap Kepatuhan Pengungkapan Wajib dalam Laporan Keuangan Pemerintah Daerah (Studi Empiris Pada Kabupaten/Kota Di Indonesia), Jurnal Akuntansi dan Auditing, Vol 8 No 1, DOI: https://doi.org/10.14710/jaa.8.1.30-42

Imas Novita Juaningsih, Yoshua Consuello, Ahmad Tarmidzi, Dzakwan NurIrfan, 2020, Optimalisasi Kebijakan Pemerintah dalam penanganan Covid-19 terhadap Masyarakat Indonesia, Salam : Jurnal Sosial dan Budaya Syar-I, Vol 7 No 6, DOI: $\underline{\text { https://doi.org/10.15408/sjsbs.v7i6.15363 }}$

Lutfil Ansori, 2015, Diskresi dan Pertanggungjawaban Pemerintah dalam Penyelenggaraan Pemerintahan, Jurnal Yuridis, Vol 2 No 1, DOI: http://dx.doi.org/10.35586/.v2i1.165

Nurhalimah, Neneng, 2020, Upaya Bela Negara Melalui Sosial Distancing dan Lockdown Untuk Mengatasi Wabah COVID-19 (Efforts to Defend the Country Through Social Distancing and Lockdown to Overcome the COVID-19 plague), SSRN, DOI: http://dx.doi.org/10.2139/ssrn.3576405 